\title{
Teachers' Perceptions of the Effect of Question-Asking Behaviour on EFL Classroom Interaction
}

\author{
Nourreddine Menyani \\ Ibn Tofail University, School of Arts and Himanities, Kenitra \\ n.menyani@gmail.com \\ Marwa Merabti \\ Ibn Tofail University, School of Arts and Himanities, Kenitra \\ merabtimarwa@hotmail.com
}

DOI: https://doi.org/10.36892/ijlls.v2i1.199

\begin{tabular}{ll}
$\begin{array}{l}\text { Received: } \\
\text { 01/01/2020 }\end{array}$ & Promoting the learning environment and the enhancement of the \\
& teaching and learning process has always been the concern of \\
Accepted: & researchers, teachers and course designers. In this respect, a \\
& considerable body of research has been concerned with the linguistic \\
& aspects of classroom interaction, many of which dealt with questioning \\
\hline Keywords: & strategies and the type of questions being employed in the EFL \\
teachers' & classroom. The main goal of this study is to explore the effect of teachers \\
questioning & questions in enhancing interaction among high school students in EFL \\
behaviour, & classrooms. It also pinpoints the features and types of questions that can \\
Teachers, & foster interaction and make the learning process more promising. Data \\
perceptions, & of this research were collected using a questionnaire, which was \\
interaction, & administered to Moroccan EFL teachers, and were analysed by \\
discourse, teaching & Statistical Package of the Social Sciences (SPSS). The findings indicated \\
and learning & that teachers'perceptions are positive towards questioning-asking as a \\
process & teaching strategy, and questions' features and types on the creation of \\
& classroom interaction and improvement of discourse. In other words, \\
& some question types significantly promoted classroom interaction while \\
& others failed to do so.
\end{tabular}

\section{INTRODUCTION}

The worldwide need for English has created an enormous demand for quality language teaching and language teaching materials and resources. Language teaching methods play a pivotal role in EFL classrooms for these methods can undoubtedly improve students' performance and boost their communication competence, once the methods are implemented effectively. Hence, teachers' primary aim has become to enable students to master English to a high level of accuracy and fluency by using a variety of techniques. According to Nhem (2019) \& Abdul-Ghafour \& Alrefaee (2019), using different language learning strategies would lead to different results of L2 learning. In this respect, the need for an appropriate teaching methodology becomes a prerequisite. Accordingly, Richards (2006) stated that "perhaps the majority of language teachers today, when asked to identify the methodology they employ, mention communicative as the methodology of choice" (p. 6). In other words, teachers are aware that learners should be encouraged and involved in the teaching and learning process to 
participate and express their ideas interactively. For this, Jeyasala (2014) asserted that teachers should provide students with spaces to interact with others or to immerse them in speaking activities that enhance their ability to use the target language. Eventually, using the language interactively cannot be accomplished without teachers questioning. Therefore, the teachers' role is central and influential to the entire process of teaching and learning. Concerning this, Chaudron (1988) claimed that questioning is one of the techniques that teachers use while teaching language. On their part, Farahian and Rezaee (2012) suggested that "teachers' questions may serve various functions such as focusing attention, exerting disciplinary control, getting feedback and most important of all, encouraging students to participate" (p. 162). In the same line of reasoning, and in relation to the functions, Cullen (1998) stated that the type of questions teachers use can have a significant effect on the quantity and quality of student interaction in an EFL classroom. In brief, Ho (2005) claimed that most of the previous "classroom-based studies have revealed the different types of questions, particularly studies on teacher questions in ESL classroom have so far revolved around the closed/open or display/referential distinction" (as cited in Rachmawaty \& Ariani, 2018, p. 40).

Question-asking is perceived as one of the most pivotal issues in the field of second language teaching. For this, teachers should account for such teaching strategy because of its preeminence in the teaching and learning process. Accordingly, Astrid, Amrina, Desvitasari, Fitriani, And Shahab (2019) reported that "questioning strategy is one of the most important dimensions of teaching and learning processes" (p. 93). Therefore, teachers might be required to employ such technique bearing in the effectiveness and the difficulty of designing or asking questions that work for the high levels of thinking, or in terms of the lack of strategies and techniques that teachers need to carry on in a classroom discourse through effective questions. Therefore, the study will focus on the issue of teachers' questions in EFL classrooms.

Any study needs a degree of significance to be valid. The reason behind the selection of this research topic has been the fact that too much attention has been given to the products of the art of teaching in Moroccan High schools so far. Confirming or rejecting the advanced hypotheses, therefore, can be a considerable contribution to the understanding of the particularities and mechanisms of the teaching and learning enterprise. As the findings may reveal unnoticed patterns of teachers questioning behavior in EFL classrooms that teachers are supposed to use in bringing positive change to their way of teaching and the outcomes can help develop improved programs for second language teachers.

This research paper will be divided into three sections, in addition to a general introduction and a general conclusion. The first section will shed light on the theoretical background of question-asking, and present a brief review of the literature that gives a general idea about teachers' questions. The second section will explain the methodology used in data collection. The third section will present the results of the study as well as an analysis of these results.

\section{REVIEW OF THE LITERATURE}

\subsection{Definitions of key terms}

\subsubsection{What is a question?}

Whenever students hear the word question, it comes to their mind that they are required to answer. The word 'question' seems to frighten students. In fact, it does since the sound of the eighth letters that form a question sounds frightening. 
The Longman Dictionary of Language Teaching and Applied Linguistics, by Richards and Schmidt (2002), provides the following definition: "An utterance that is addressed to a listener/ reader and asks for an expression of fact, opinion, belief, etc." (p. 476). Another definition provided by Oxford Advanced Learner's Dictionary defines a question as "A sentence, phrase or word that asks for information" or "a matter or topic that needs to be discussed or dealt with" (Hornby, 2006, p. 1037). There are different types of questions but the focus of this study is based on two broad ones which are display and referential questions.

\subsubsection{Display questions}

Display questions refer to the questions to which the teacher already knows the answer. They are asked to check if the students know the answers or not. Moreover, they are also used to establish the addressee's knowledge of the answers. As noted above, teachers ask display questions to evaluate their students' level, only to find out whether they have got the lesson or not. Van Lier (1988) has questioned the value of distinguishing display and referential questions, pointing out that:

display questions have the professed aim of providing comprehensible input and of encouraging early production. What gives such question types their instructional, typically L2 classroom character, is not so much that they are display rather than referential, but that they are made to elicit language from learners. (p. 222)

According to Van Lier (1988), the important distinction between questions in a classroom is the fact that classroom questions, of whatever sort, are designed to have learners produce language. Thus, what distinguishes instructional from non-instructional (conversational) questions is their eliciting function, not their referential or display nature.

In the case of display questions, the teachers know the answer and the students are supposed to know the answer as well. Basically, this kind of questions serves to check the previous knowledge of the pupils or to test what they have already learned. In short, the following example of a classroom situation where the teacher asks a display question is the best illustration:

\section{T: and then we know that Mr. Archer came on his own... what does this house consist of? Tell me about this house. Yes, Mohammed.}

S: It's a villa with a large garden.

T: yes

(Nunn, 1999, p. 23)

Similarly, Grice (1989) explained that a display question is a question to which the answer is already known by the initiator. In real communication, asking such questions violates the 'maxim of quality' according to Grice's principle of co-operation in conversation. According to Grice, the addresser of a question in a real social context seeks new and unknown information from the addressee, who is expected to give a true and sincere answer. Therefore, asking a display question in real communication would be considered 'insincere' and might not receive the desired response from the addressee (As cited in Kao, Carkin, \& Hsu, 2011).

The use of display questions, which reflects the one-way flow of information from teachers to students, is responsible for the fact that conversations in classroom discourse must be separated from the demands of everyday discourse. This is because there is only a single correct response to display questions, and it is known in advance. Teachers often find 
themselves searching for that answer, while students provide various trial responses that are in search of validation as the correct answer, and this is the unique nature of the classroom conversation produced by display questions.

\subsubsection{Referential questions}

Referential questions tend to provide contextual information about situations, events, actions, purposes, relationships or properties (Wh-questions for example). In this case, the teacher does not know the answer, and the students answer the questions to give the teacher information. Brock (1986) stated that "Referential questions request information not known by the questioner" (p. 48). In other words, the teacher asks something to which he or she does not know the answer. An example of a referential question would be "what is your personal opinion towards the re-election of George W. Bush?" (As cited in Becker, 2009, p. 3). By asking referential questions, teachers' objective is to elicit first-hand information from the students.

Accordingly, Kao, et al. (2011) stated that a referential question, which aims to elicit unknown information to the initiator, dominates the majority of questions asked in real situations. In the classroom, a referential question's main concern is to draw answers referring to learners' opinions, judgements, and real-life experiences, with the function of filling in the information gaps. The answers are usually longer than for display questions and carry content meanings. Teachers use referential questions more often when managing the class.

\subsubsection{Open and closed questions}

In contrast to display and referential questions, the classification of open and closed questions is much more difficult to accomplish. Although we can assert that closed questions deliver a limited amount of possible responses, and the open questions leave the respondent with a wider range of options to answer, there can be questions which may be open in form but closed in function (Dalton- Puffer, 2007, p. 97).

While the typically closed question is mostly "one which asks for the short right answer" or " one which may be answered by 'yes' or 'no', the open question is one which suggests that the teacher does not have one particular answer in mind but is inviting students to consider and advance many possibilities (Morgan and Saxton 1993, p. 63).

By using open questions, the teacher tends to encourage students to talk more freely and leave more space for improvisation. Conversely, open questions increase the chance to receive a more complex answer, which may lead the teacher to lose the conversational control and put higher demands on the questioner in terms of an appropriate reaction (Dalton-Puffer 2007, p. 97). In contrast, the teacher asks a closed question if he/she aims to continue with his/her topic without further discussion. It also provides him or her with a chance to help students who are reluctant to talk because they have a chance to give a short pregnant answer and do not need to show their personal opinion. Dalton-Puffer (2007) provided some statistical numbers, which show that teachers generally tend to use display questions and closed ones.

Overall, closed questions limit themselves to yes/ no questions. Yet, all other questions have to be considered open and are said to typically begin with words like what, how, why, where, and to receive longer and more complex answers. For instance, Becker (2009, p.3) illustrated closed and open questions as follows: 


\section{Closed questions}

Did anybody of you try to drive already?

Was that a four-star-star hotel?

Do you really think that parents know what their kids are doing just by calling them

Open questions

Who fought against whom in the First World War?

How was it under water?

What would be the result of dropping a hundred percent of my products, Martin

Who are the rich men in an early society?

Why the cold was going so long?

However, it quickly becomes, while analysing these questions, evident that the formal criteria introduced above are somehow problematic, and researchers have noted the difficulty of distinguishing between open and closed questions in practice. Identification by opener alone is certainly not reliable since some questions may be open in form but closed in function in a specific situation. Consequently, subsequent discourse often reveals that a teacher was, in fact, in fact seeking a particular answer even though the question looked open. (Cazden \& Beck, 2003, p. 177)

Researchers and other writers who are concerned with questioning techniques seem to emphasize the fact that questioning has a long and venerable history as an educational strategy. Indeed, the Socratic Method of using questions and answers to challenge assumptions to expose contradictions, and lead to new knowledge.

In addition to its long history and demonstrated effectiveness, questioning is also of interest to researchers and practitioners because of its widespread use as a contemporary teaching technique. With regard to this, question asking has received paramount importance in the field of teaching. Therefore, the following sections will highlight the important issues that are related to questioning such as how is question-asking important in the field of education? What are the types of questions that receive great attention? How can the type of question used affect the learning process of students? What are the characteristics of a good question?

\subsection{The importance of question asking}

Effective teaching does not necessarily depend only on presenting the lesson to the students, but it goes beyond that. Concerning this, Morgan and Saxton (1991) revealed that "whatever the plan, the strategy or technique, effective teaching depends primarily upon the teacher's skill in being able to ask questions which generate different kinds of learning" (p. 3). Phrased differently, using questions, especially of different kinds, has become mandatory if the teacher intends to be effective in his/her teaching. This leads to the fact that teachers' questions are not only tools for evaluating how much students learn, but they are means that lead students to have better understandings of the structure of knowledge and its importance in their lives. In this respect, Hunkins (1995) stated that:

We are shifting from viewing questions as devices by which one evaluates the specific of learning to conceptualizing questions as a means of actively processing thinking about, and using information productively. Many educators are weaning students from believing that questions are phrased to attain certain answers and are helping them to 
accept questions as key vehicles that elicit awareness of the diversity, complexity, and richness of knowledge.

(As quoted in Walsh and Sattes, 2005, p. 4)

The importance of asking questions does not only lie in making students having good knowledge, but also in keeping them in the process of thinking. That is to say, when a teacher asks a question, the student's answer should be only an initial step to a process of thinking. The question should drive students to think of a response, and at the same time make them ask their questions.

The questioning process is not only for eliciting answers from students but also for keeping them thinking and learning beyond an initial correct response. What teachers do with students' responses (e.g. move students to ask their own questions or to extend a peer's response) has a dramatic impact on the extent to which students continue their journey of thinking and learning. (Wash \& Sattes, 2005).

Teachers' questions have a positive effect on the academic life of students. According to Sigel and Saunder (1979) "questioning is critical because it requires children to distance themselves in time and space from the present. When responding to questions about past or future events, the students shift from the present to other distant made of thought" (Cecil, 1995, p. xxx). Therefore, it can be concluded that questions help students move from real life situations or moments to imaginary locations. Questions can also be a stimulus that motivates them to learn. Correspondingly, Cecil (1995) stated that "by asking questions we are adding a rich source of fuel to students "motivation for learning." When a teacher asks a question, students are encouraged to think and use their cognitive abilities to find an answer, and at the same time, this helps them promote their background knowledge.

Following the same line of reasoning, questions promote students learning. They enable learners to have good understandings of knowledge, and at the same time help them keep their process of thinking. They are the means that challenge students to approach their learning creativity. That is why teachers are advised to plan his/her questions before asking them. In other words, to guarantee that teachers' questions will lend a hand to achieve the instructional objectives of the lesson and develop the students thinking process, a teacher should not question his/ her student randomly, but s/he has to plan his/her questions. This was also advocated by Wash \& Sattes (2005) claimed that "teachers should plan their questions before asking to ensure that questions match the instructional objectives and promote thinking. Often carefully prepared or selected questions are preferable to a large number of questions" (p. 12).

\subsection{The use of questions in traditional and modern classrooms}

The environments and the conditions under which students learn affect the use of question-asking strategy. Knowledge in traditional classrooms is, most of the time, related to the teacher. In other words, a teacher is the only source of knowledge and students are only receivers to this knowledge. Therefore, teachers' questions in traditional classrooms are only used to evaluate students' ability to remember information. This has been asserted by Morgan \& Saxton (1991) when they claimed that "the majority of questions entail the recall and recitation of factual information previously taught or studied, some few questions hear on speculation, evaluative and other cognitive manipulations of information, and the remainder area conventional and managerial" (p. 102). 
In contrast, modern classrooms use questions for different purposes. They view questions as essential elements for the teaching and learning process. The types of questions that teachers opt for are not for evaluating students' recall of what they have learned, but for enhancing interaction with both the teacher and the rest of students, and for reaching a complete understanding. Since modern classrooms view learning as a social activity that requires students to be not only receivers but also to be constructors of knowledge, we can conclude that modern classrooms are learner-centered.

Having learner-centered classrooms requires that teachers construct certain knowledge and skill that will help them to achieve that goal. Traditional teachers are able to make students more active and interactive in their classrooms, but they have to receive professional training, especially on how to give quality questioning. Considering this, Walsh and Sattes (2005) stated that "we teachers must focus our professional learning upon knowledge, skill, and beliefs that will enable us to move from the traditional classroom in which most of us spent our years as students to the more student-centered inquiry-oriented classroom embodies in what we call a quality questioning classroom" (p. 371).

Walsh and Sattes (2005) went on saying that the majority of teachers are conscious of the characteristics of quality questions. When you ask a teacher about the questions that will help students have a better understanding, and at the same time make them use their minds s/he will inform you. However, the problem is putting words into practice because once they step into their classrooms they forget all these things. They further pinpointed that "most teachers with whom we have worked over the years agree that we know much more about quality questioning than we put into practice" $(2005$, p. 15). In practical terms, there are reasons why teachers do not always follow best practice according to Walsh \& Sattes (2005) who revealed that "without fail, the following issues emerge as barriers to best practices: content coverage, time constraints, habit or tradition, a felt need to maintain "control" of class, ease for a teacher, not wanting to embarrass students" (p. 16).

Being able to ask good questions in classrooms necessitates certain requirements. First, it is based on whether teachers understand that students must think in order to learn. Second, whether they know how to provoke, stimulate and support students' thinking. It also requires skill, time and training. In essence, Walsh \& Sattes (2005) suggested that "changing our questioning behaviors is a journey, a process that can occur over time when individuals develop the will and the skill, and when they have an appropriate framework and support" (p. 10).

\subsection{The use of higher and lower-level questions}

In their review concerning question asking in EFL classrooms, Redfield and Rousseau (1981) concluded that the use of higher-level questioning is positively related to improving students' achievement. In contrast, other researchers have concluded that young students and low-income students, who are learning basic skills, benefit most from low-level questions. Whereas middle and high school students, appear to have higher achievement when exposed to more higher-level questions. (Wash \& Sattes, 2005, pp. 12-13).

As can be noticed, most researches on teacher questions have different results. Some of them argue that the effect of display questions on students' discourse pattern was generally considered to be negative. Basically, Goodwin (2006) argued that:

Pupils' responses tend to be short, and the teacher doesn't encourage elaboration of responses when the display questions are asked. Other researchers claimed that display 
questions and closed questions still have the function of the teacher to check the students' state of knowledge and provide them with opportunities for practicing language form. (As cited in Myhill, Jones \& Hopper, 2006, p. 15)

Concerning high cognitive questions, it can be deduced that high cognitive level questions improve students' achievements. They require students to provide long and complex answers. Concerning this, Cooper (1976) suggested that "there is a growing consensus that higher-order questions increase the level of students thinking and lead to an increase in student achievement" (p. 109), yet there are others who claimed the opposite. For instance, Walsh and Sattes (2005) stated that "even with the differences in the findings, most researchers conclude that higher-level questions promote the development of thinking and skills" (p. 13).

Asking high-level cognitive questions will enable students to develop their cognitive abilities. It will also help them provide answers that are not brief with little elaboration, but answers that are long and syntactically complex. Walsh and Sattes (2005,) affirmed that "teachers should purposefully plan and ask questions that require students to engage in higherlevel thinking. Teachers should also help students become familiar with the different levels of thinking and help them be aware of the kind of thinking required by the question" (p. 13).

They also went on saying that to ensure the development of students' cognitive abilities a teacher should carefully prepare and select the type of questions that s/he will use within the classroom. Questioning is not only a strategy for eliciting responses from students during the whole class teaching but also a means for promoting students' cognitive abilities.

\subsection{Characteristics of good questions}

To highlight the necessity for effective teaching, there has been a great demand for better question asking. To accomplish that, some researchers designed certain characteristics of good questions that should be taken into consideration. In effect, Dilon, (1983) noted that effective questioning advance learning and thinking. Furthermore, good questions are those that increase students' participation and curiosity (Anderson, \& Knathal, 2001; Bloo, 1987). In this respect, the purpose behind asking questions in the classroom should match the objective for which students are learning, and provide them with opportunities to express their thought, and boost their level of participation and curiosity. Similarly, Morgan \& Saxton (2006) claimed that "a good question is an expressive demonstration of a genuine curiosity" (p. 77). In other words, questions should not be asked randomly, but there must be an intention to know, questions should be reasonable. Morgan \& Saxton (2006) added that "a good question has an inner logic related in some way to the teacher's focus, and student's experience" (p. 77). In this sense, questions should be in favor of both teachers, and students. Moreover, Morgan \& Saxton (2006) further stated that "good questions words are ordered in such a way that thinking is clarified both for the teachers, and students" (p. 77). That is to say, questions should be logically organized in a way, students will focus their thinking on a specific way; teachers also can have an idea about the students' thinking.

Additionally, Morgan \& Saxton (2006) concluded that "in good questions the intent must be supported by intonation and nonverbal signals" ( $\mathrm{p}$. 77). In other words, the pace of the question should fit the intent. Simply put, the way a question is asked should reflect the intended message because the nature of the question determines how it is asked. Moreover, good questions can provide surprise, students will sometimes respond to a good question by talking about things that neither they nor the teacher was aware of (Morgan \& Saxton, 2006, 
p. 78). In fact, this kind of question can have different answers from different students because they are often related to one's personal experience. A good question challenges thinking and encourages reflection. That is to say, good questions go beyond thinking because students need to reflect upon their own experiences.

\subsection{Summary}

The review of the related literature has been an attempt to tackle an issue, which is concerned with question-asking in the EFL classroom. It has been found that there are two broad different types of questions namely, display and referential questions. The former, which reflects the one-way flow of information from teachers to students is used only to find out whether students understand the lesson or not, while the latter is used to elicit first-hand information from the students. In addition to that, previous studies have shown that to make students able to communicate, the teacher should not dominate the questioning, and s/he has to bear in mind that higher-level cognitive questions might increase the length and syntactic complexity of students' speech.

\section{METHODOLOGY}

The major purposes of this exploratory study are to investigate teachers' perceptions of the effects of questions on the learning process of high school students and see to what extent questions make the lesson successful as far as the learning process is concerned. This section aims to describe the methodology of the present study. It includes a presentation of the various research methodological aspects: subjects, instrumentation, and procedure.

\subsection{Informants and the instrument of the research}

\subsubsection{The population sample}

The subjects are thirty Moroccan English High School Teachers in Fes-Meknes region. The informants involve both males (17) and females (13). The main criterion on which the selection of subjects has been based on is their availability. That is to say, all the subjects have been conveniently selected. In brief, this research opted for convenience sampling as a sampling technique.

\subsubsection{Data gathering instrument}

The data gathering instrument used in the process of collecting the data is the questionnaire. The choice of this technique is related to the positive characteristics it has. Questionnaires are inexpensive ways to gather data from a potentially large number of respondents (the example here of teachers of English). They are often the only feasible way to reach many reviewers large enough to allow easy statistical analysis of the results. A welldesigned questionnaire that is used effectively can yield salient information.

In terms of the form, the questionnaire that was designed to fit the research context contained eighteen questions. It is a combination of multiple-choice questions and open-ended questions. The two types are interconnected since the former makes the target sample limits the answers to the points that are meant to be analyzed in the research, and the open-ended questions provide them with the opportunity to elaborate more on them and give other clarifications. To ensure valid results, we opted for Cohen's $d$ formula (1988) which contains magnitudes of $d=0.2$ to 0.8 , and which was expanded by Sawilowsky (2009) to reach 2.0. This 
formula is defined as follows: Cohen's $d=\left(M_{\text {sample }}-\mu_{\text {population }}\right) / \sigma$, where Cohen's $d=(15.5-50.5) /$ $28.8=1.2$.

\subsubsection{The focus of the questionnaire}

In terms of its focus, the questionnaire gives more priority to the importance of question-asking in Moroccan EFL/ ESL high schools and the effects of questioning on the process of teaching and learning performance. The focus is mainly based on the following hypotheses and research questions.

\subsubsection{The hypotheses}

As has already mentioned, the qualitative side of this small-scale study intends to answer three research questions. The following hypotheses are shaped according to these questions:

1. There is no difference in the distribution of teachers' display and referential questions in Moroccan EFL classrooms.

2. Referential questions create more interaction in the classroom than display or other types of questions do.

3. Teachers think that the questions they ask affect EFL classroom interaction as well as the learning process.

\subsection{Research questions}

1. Is there any difference in the distribution of teachers' display and referential questions in Moroccan EFL classrooms?

2. Are referential questions equal to their interactive effects as well as the other types of questions are concerned?

3. What do teachers think of the effect of their questions on EFL classroom interaction as well as on the learning process?

\section{DATA ANALYSIS AND DISCUSSION}

The purpose of this section is to describe, analyse and discuss, in details, the collected data obtained from the questionnaire, which was administered to 30 Moroccan EFL High School Teachers. In this respect, the obtained data including the Likert-scale questions were analysed with the help of the SPSS program. In short, the overall analysis of the obtained data was carried out in accordance with the research questions of this study and in alignment with the survey questions. Overall, the findings of this research are described in details in what follows.

Table 1: The importance of question asking

\begin{tabular}{llcccc}
\hline & Frequency & Percent & Valid Percent & $\begin{array}{c}\text { Cumulative } \\
\text { Percent }\end{array}$ \\
\hline \multirow{2}{*}{ Valid } & Very important & 20 & 87,0 & 87,0 & 87,0 \\
\cline { 2 - 6 } & Less important & 1 & 4,3 & 4,3 & 91,3 \\
\cline { 2 - 6 } & Important & 2 & 8,7 & 8,7 & 100,0 \\
\cline { 2 - 6 } & Total & 23 & 100,0 & 100,0 & \\
\hline
\end{tabular}


Table 1 deals with the first question, which is the importance of question-asking. As the results indicated in the table above, the number of teachers who considered the use of questions in the classrooms very important represented 87.0\%, and the number of teachers who considered it important represented $8.7 \%$. In contrast, $4.3 \%$ of the informants considered question asking less important.

\section{Table 2: Questioning should be part of the learning and teaching process}

\begin{tabular}{llcccc}
\hline & Frequency & Percent & $\begin{array}{c}\text { Valid } \\
\text { Percent }\end{array}$ & $\begin{array}{c}\text { Cumulative } \\
\text { Percent }\end{array}$ \\
\hline \multirow{2}{*}{ Valid } & no answer & 3 & 13,0 & 13,0 & 13,0 \\
\cline { 2 - 5 } & checking the understanding & 2 & 8,7 & 8,7 & 21,7 \\
\cline { 2 - 5 } & important as a communication tool & 10 & 43,5 & 43,5 & 65,2 \\
\hline developing skills & 2 & 8,7 & 8,7 & 73,9 \\
\hline getting feedback & 2 & 8,7 & 8,7 & 82,6 \\
\hline facilitating teaching learning process & 4 & 17,4 & 17,4 & 100,0 \\
\hline Total & 23 & 100,0 & 100,0 & \\
\hline
\end{tabular}

To find out about the inclusion of question-asking in the teaching and learning process, teachers were required to answer the question of why questions should be part of the learning and teaching process. According to the findings, as shown in Table 2, $87 \%$ of the informants seemed to agree on the importance of questioning in the teaching and learning process differing only in the interpretation of the role of questioning. In this respect, $43.5 \%$ of the informants reported that it is important as a communication tool, and $17.4 \%$ of the participants claimed that questioning is important for it facilitates the teaching and learning process. While others reported that it is important for checking the understanding, developing skills, getting feedback ( $8.7 \%$ for each). Unfortunately, $13 \%$ of the respondents provided no answer.

\section{Table 3: Questions aim}

\begin{tabular}{llcccc}
\hline & Frequency & Percent & $\begin{array}{c}\text { Valid } \\
\text { Percent }\end{array}$ & $\begin{array}{c}\text { Cumulative } \\
\text { Percent }\end{array}$ \\
\hline Valid & 1 & 4,3 & 4,3 & 4,3 \\
\cline { 2 - 5 } & no answer & 11 & 47,8 & 47,8 & 52,2 \\
\cline { 2 - 5 } checking comprehension & 7 & 30,4 & 30,4 & 82,6 \\
\cline { 2 - 5 } & involving students & 3 & 13,0 & 13,0 & 95,7 \\
\cline { 2 - 5 } & Interaction & 1 & 4,3 & 4,3 & 100,0 \\
\cline { 2 - 5 } $\begin{array}{l}\text { creating problem solving } \\
\text { situations }\end{array}$ & 23 & 100,0 & 100,0 & \\
\hline & Total & & & \\
\hline
\end{tabular}

Identifying the aim behind asking questions was also one of the objectives of this research. For this, the informants were required to answer the question based on the items given. As suggested in Table 3, questions are generated for different aims. In this regard, 47.8\% of respondents stated that the aim behind question asking is to check students' comprehension, $30.4 \%$ claimed that questions aim to involve students, and $13.00 \%$ informed that interaction is one of the most important aims of questioning. To a lower extent, $4.3 \%$ of the respondents argued that questions aim to create problem-solving situations. Unfortunately, $4.3 \%$ of the participants did not provide an answer. 
Table 4: Questions make the learning process successful

\begin{tabular}{llcccc}
\hline & Frequency & Percent & $\begin{array}{c}\text { Valid } \\
\text { Percent }\end{array}$ & $\begin{array}{c}\text { Cumulative } \\
\text { Percent }\end{array}$ \\
\hline Valid & no answer & 4 & 17,4 & 17,4 & 17,4 \\
\cline { 2 - 6 } & making the lesson successful & 8 & 34,8 & 34,8 & 52,2 \\
\cline { 2 - 6 } & learners involvement & 3 & 13,0 & 13,0 & 65,2 \\
\cline { 2 - 6 } & boosting critical thinking & 2 & 8,7 & 8,7 & 73,9 \\
\cline { 2 - 6 } & checking understanding & 5 & 21,7 & 21,7 & 95,7 \\
\cline { 2 - 6 } & graded from simple to complex & 1 & 4,3 & 4,3 & 100,0 \\
\cline { 2 - 5 } & Total & 23 & 100,0 & 100,0 & \\
\hline
\end{tabular}

Table 4 represented teachers' perceptions about questions in making the learning successful. As it is reported in the table above, the majority of the respondents insisted on the importance of questioning in the teaching and learning process. For instance, $34.8 \%$ of the informants said that questions play an important role in making the lesson successful. In this regard, $21.7 \%$ of the participants emphasized on questions as a crucial element for checking students' understanding, while $13 \%$ of the respondents insisted on questions as a means for involving students in the learning process. Additionally, $8.7 \%$ of the subjects agreed on the ideas that questions are tools for boosting students' critical thinking. To a lower degree, $4.3 \%$ of the informants agreed on grading learning from simple to complex.

\section{Table 5: Questions encourage students to learn}

\begin{tabular}{cccccc}
\hline & Frequency & Percent & Valid Percent & $\begin{array}{c}\text { Cumulative } \\
\text { Percent }\end{array}$ \\
\hline \multirow{2}{*}{ Valid } & no answer & 1 & 4,3 & 4,3 & 4,3 \\
\cline { 2 - 6 } & yes & 21 & 91,3 & 91,3 & 95,7 \\
\cline { 2 - 6 } & no & 1 & 4,3 & 4,3 & 100,0 \\
\cline { 2 - 6 } & Total & 23 & 100,0 & 100,0 & \\
\hline
\end{tabular}

The data presented in Table 5 above highly revealed that questions encourage students to learn because $91.3 \%$ of the informants provided a yes answer when asked do you think questions encourage students to learn. However, $4.3 \%$ of the informants stated that questions do not encourage students to learn. Whereas, $4.3 \%$ of the informants provided no answer.

Table 6: Frequency of asking questions

\begin{tabular}{llcccc}
\hline & & Frequency & Percent & Valid Percent & $\begin{array}{c}\text { Cumulative } \\
\text { Percent }\end{array}$ \\
\hline \multirow{2}{*}{ Valid } & Always & 15 & 65,2 & 65,2 & 65,2 \\
\cline { 2 - 6 } & Usually & 8 & 34,8 & 34,8 & 100,0 \\
\cline { 2 - 6 } & Total & 23 & 100,0 & 100,0 & \\
\hline
\end{tabular}

Identifying the frequency of question-asking within the EFL classroom was also one of the concerns of this study. Hence, the data presented in Table 6 are very suggestive because they showed that questions are frequently used. In effect, $65.2 \%$ of the informants indicated that they always use questions, while $34.8 \%$ of the participants revealed that they usually use questions. 
Table 7: Question types

\begin{tabular}{llcccc}
\hline & Frequency & Percent & $\begin{array}{c}\text { Valid } \\
\text { Percent }\end{array}$ & $\begin{array}{c}\text { Cumulative } \\
\text { Percent }\end{array}$ \\
\hline Valid & Display Questions & 1 & 4,3 & 4,3 & 4,3 \\
\cline { 2 - 6 } & Both of them & 22 & 95,7 & 95,7 & 100,0 \\
\cline { 2 - 6 } & Total & 23 & 100,0 & 100,0 & \\
\hline
\end{tabular}

From the table above, it is obvious that most teachers use both referential and display questions. In this respect, $95.7 \%$ of the informants use the two different types, whereas only $4.3 \%$ of the informants make use of display questions.

Table 8: The rate of questions' use

\begin{tabular}{llcccc}
\hline \multirow{2}{*}{ Valid } & Frequency & Percent & $\begin{array}{c}\text { Valid } \\
\text { Percent }\end{array}$ & $\begin{array}{c}\text { Cumulative } \\
\text { Percent }\end{array}$ \\
\cline { 2 - 6 } & No answer & 8 & 34,8 & 34,8 & 34,8 \\
\cline { 2 - 6 } & Referential questions & 7 & 30,4 & 30,4 & 65,2 \\
\cline { 2 - 6 } & Display questions & 2 & 8,7 & 8,7 & 73,9 \\
\cline { 2 - 6 } & DQs and RQs & 6 & 26,1 & 26,1 & 100,0 \\
\cline { 2 - 6 } & Total & 23 & 100,0 & 100,0 & \\
\hline
\end{tabular}

Being issued as one of the research elements, the rate of use of display and referential questions would say much about the learning outcomes. In essence, the informants were required to report how often they use the types of questions given to them. The findings presented in the Table above indicated that $30.4 \%$ of the informants, most of the time, use referential questions, and $26.1 \%$ of the respondents use both referential and display questions. On the other hand, only $8.7 \%$ of the informants use display questions, while $34.8 \%$ of the informants provided no clear cut answer.

\section{Table 9: Students' response}

\begin{tabular}{llcccc}
\hline & Frequency & Percent & $\begin{array}{c}\text { Valid } \\
\text { Percent }\end{array}$ & $\begin{array}{c}\text { Cumulative } \\
\text { Percent }\end{array}$ \\
\hline \multirow{2}{*}{ Valid } & No answer & 1 & 4,3 & 4,3 & 4,3 \\
\cline { 2 - 6 } & More to referential Qs & 6 & 26,1 & 26,1 & 30,4 \\
\cline { 2 - 6 } & More to display Qs & 11 & 47,8 & 47,8 & 78,3 \\
\cline { 2 - 6 } & To both of them & 5 & 21,7 & 21,7 & 100,0 \\
\cline { 2 - 6 } & Total & 23 & 100,0 & 100,0 & \\
\hline
\end{tabular}

Table 9's main concern is related to the percentage of students' responses to display and referential questions. It is obvious, from Table 9 above, that students' responses go to display questions (47.8\%) more than to referential questions (26.1\%). Additionally, $21.7 \%$ represented the number of students who respond to both. While $4.3 \%$ of the informants provided no answer. 
Table 10: How often do you plan questions?

\begin{tabular}{llcccc}
\hline & & Frequency & Percent & Valid Percent & $\begin{array}{c}\text { Cumulative } \\
\text { Percent }\end{array}$ \\
\hline \multirow{2}{*}{ Valid } & Sometimes & 6 & 26,1 & 26,1 & 26,1 \\
\cline { 2 - 6 } & most of the time & 2 & 8,7 & 8,7 & 34,8 \\
\cline { 2 - 6 } & Always & 9 & 39,1 & 39,1 & 73,9 \\
\cline { 2 - 6 } & yes, no & 2 & 8,7 & 8,7 & 82,6 \\
\cline { 2 - 6 } & Rarely & 1 & 4,3 & 4,3 & 87,0 \\
\cline { 2 - 6 } & No & 3 & 13,0 & 13,0 & 100,0 \\
\cline { 2 - 5 } & Total & 23 & 100,0 & 100,0 & \\
\hline \hline
\end{tabular}

As it is represented in Table 10, the number of informants who always plan their questions represented $39.1 \%$, and those who plan them sometimes represent $26.1 \%$. $8.7 \%$ of the informants plan their questions most of the time and $8.7 \%$ of the informants answer with yes and no, and those who rarely plan their questions don't exceed $4.3 \%$. Whereas those who do not plan their questions represent $13 \%$ of the informants.

Table 11: The way questions are addressed

\begin{tabular}{llcccc}
\hline & Frequency & Percent & $\begin{array}{c}\text { Valid } \\
\text { Percent }\end{array}$ & $\begin{array}{c}\text { Cumulative } \\
\text { Percent }\end{array}$ \\
\hline \multirow{2}{*}{ Valid } & no answer & 5 & 21,7 & 21,7 & 21,7 \\
\cline { 2 - 6 } & Directly & 3 & 13,0 & 13,0 & 34,8 \\
\cline { 2 - 6 } & Indirectly & 2 & 8,7 & 8,7 & 43,5 \\
\cline { 2 - 6 } & directly and indirectly & 13 & 56,5 & 56,5 & 100,0 \\
\cline { 2 - 6 } & Total & 23 & 100,0 & 100,0 & \\
\hline
\end{tabular}

The findings in Table 11 indicated, on the one hand, that most $(56.5 \%)$ of the informants addressed questions both directly and indirectly. On the other hand, only (13.0\%) of the participants reported that they address their questions directly, whereas those who address their questions indirectly represented only $8.7 \%$.

Table 12: Verbal- non-verbal questions

\begin{tabular}{llcccc}
\hline & Frequency & Percent & Valid Percent & $\begin{array}{c}\text { Cumulative } \\
\text { Percent }\end{array}$ \\
\hline \multirow{2}{*}{ Valid } & no answer & 2 & 8,7 & 8,7 & 8,7 \\
\cline { 2 - 6 } & all verbal & 9 & 39,1 & 39,1 & 47,8 \\
\cline { 2 - 6 } & most of them & 12 & 52,2 & 52,2 & 100,0 \\
\cline { 2 - 5 } & Total & 23 & 100,0 & 100,0 & \\
\hline
\end{tabular}

The findings, in Table 11 above, revealed that the rate of the informants who use verbal questions most of the time is high $(52.2 \%)$ in comparison to those who resort to verbal questions all the time (39.1\%). Surprisingly, none of the respondents uses non-verbal questions.

Table 13: Students' level determines teachers' questions

Frequency Percent Valid Percent $\quad$ Cumulative Percent




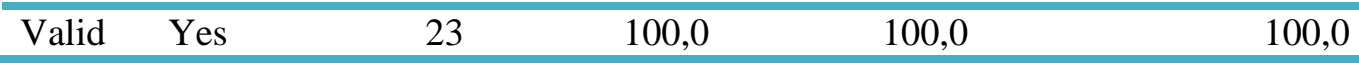

To find out about teachers' perceptions of students' level in determining the type of questions teachers use, the informants were required to respond to a direct question regarding this point. From the results in Table 13, it is obvious that all (100\%) informants agreed that the students' level determines their questions.

\section{Table 14: Questions variation}

\begin{tabular}{lccccc}
\hline & & Frequency & Percent & Valid Percent & Cumulative Percent \\
\hline Valid & Yes & 23 & 100,0 & 100,0 & 100,0 \\
\hline
\end{tabular}

Varying questions would yield promising learning outcomes. For this, informants were required to state if teachers are to vary their questions or not. As shown in Table 14, all (100\%) the informants agreed on the idea that teachers' questions should be varied.

Table 15: In which part of the lesson do you ask more questions?

\begin{tabular}{llcccc}
\hline & & Frequency & Percent & Valid Percent & Cumulative Percent \\
\hline \multirow{2}{*}{ Valid } & Presentational stage & 12 & 52,2 & 52,2 & 52,2 \\
\cline { 2 - 6 } & While stage & 1 & 4,3 & 4,3 & 56,5 \\
\cline { 2 - 6 } & Post stage & 1 & 4,3 & 4,3 & 60,9 \\
\cline { 2 - 5 } & All stages & 9 & 39,1 & 39,1 & 100,0 \\
\cline { 2 - 5 } & Total & 23 & 100,0 & 100,0 & \\
\hline
\end{tabular}

Item 15 was asked to see the phase of the lesson where the teacher asks more questions. The results in Table 15 indicated that $52.2 \%$ of the informants use questions in the presentation stage. To a lower extent, $39.1 \%$ of the participants use questions in all stages. Whereas only $4.3 \%$ of the informants ask questions during the while stage, and $4.3 \%$ of the informants ask questions in the post-stage of the lesson.

Table 16: Frequency to ask a question to check comprehension

\begin{tabular}{llcccc}
\hline & & Frequency & Percent & Valid Percent & Cumulative Percent \\
\hline \multirow{3}{*}{ Valid } & Always & 20 & 87,0 & 87,0 & 87,0 \\
\cline { 2 - 6 } & Sometimes & 3 & 13,0 & 13,0 & 100,0 \\
\cline { 2 - 6 } & Total & 23 & 100,0 & 100,0 &
\end{tabular}

The table above reveals the frequency of asking questions to check students' comprehension. According to the findings presented in Table 16, the rate of asking questions frequently is high because $87 \%$ of the informants always ask questions to check their students' understanding, while $13 \%$ of the respondents reported that they sometimes ask questions to check students' understanding.

Table 17: Do your questions focus only on one skill or different skills?

\begin{tabular}{llcccc}
\hline & Frequency & Percent & $\begin{array}{c}\text { Valid } \\
\text { Percent }\end{array}$ & $\begin{array}{c}\text { Cumulative } \\
\text { Percent }\end{array}$ \\
\hline \multirow{2}{*}{ Valid } & No answer & 1 & 4,3 & 4,3 & 4,3 \\
\cline { 2 - 6 } & The focus on one skill & 1 & 4,3 & 4,3 & 8,7 \\
\cline { 2 - 6 } & The focus on different skills & 21 & 91,3 & 91,3 & 100,0 \\
\cline { 2 - 6 } & Total & 23 & 100,0 & 100,0 & \\
\hline
\end{tabular}


Concerning the skills that teachers focus on while question asking, the results, as shown in Table 17, implied that $91.3 \%$ of the informants agreed on the idea that questions should focus on different skills. In contrast, $4.3 \%$ of the participants declared that their questions focus only on one skill. Yet, $4.3 \%$ of the subjects provided no answer.

\section{Table 18: Teaching without questions}

\begin{tabular}{|c|c|c|c|c|c|}
\hline & & Frequency & Percent & Valid Percent & Cumulative Percent \\
\hline Valid & No & 23 & 100,0 & 100,0 & 100,0 \\
\hline
\end{tabular}

This item deals with the question stating whether teachers can teach without questions. The findings reported in Table 18 revealed that $100 \%$ of the informants emphasize the idea that without questions teaching is impossible.

\section{DATA INTERPRETATION AND DISCUSSION}

The main concern of this section is discussing and interpreting the study's findings of the obtained data presented in the previous section. This, of course, has been undertaken in light of the research questions and the theoretical framework discussed in the review of the literature. In other words, this section attempts to provide answers to research questions, and hypotheses raised at the beginning of this research. In essence, the study focuses on teachers' perception of the effect of question-asking on EFL classroom interaction.

It has evidently been stated in the results section that referential questions outnumber display questions in terms of teachers' use. This is clearly proved in the data analysis since $30.4 \%$ of respondents use referential questions and few informants use display questions $8.7 \%$. However, there is a balance in distributing both referential and display questions. Furthermore, some informants provided no clear answer which is once again very significant. Moreover, it is further observed that referential questions lead to more classroom interaction, and increase students' critical thinking. Similarly, the findings of this research corroborate with the findings of a study carried out by Coper (1976) who argues that the increase of students' thinking and achievement is highly dependent on asking higher-order questions (referential questions).

From the reported results, it is also evident that teachers are aware of the importance of using referential questions in the EFL classrooms. Significantly, referential questions instigate genuine communication and allow students to express opinions and exchange information. Additionally, referential questions also can be used as communication tools for eliciting information from students. Moreover, questioning should be used to boost communication. This is consistent with Elenein (2019) whose study insisted and recommended on developing learners' oral communication. Yet, the low rate of the use of display questions indicates that teachers might not be aware of the weakness of display questions on the interaction process. The use of display questions implies that they have a daily routine and adds no quality to students' performance. Overall, the findings of this study are in accordance with the findings reported by other researchers such us Godwin (2006) who finds out that display questions have a negative effect on learners. and Dalton-Puffer (2005) who concludes that the use of display questions is, therefore, odd, and is also routinely used.

Eventually, the findings of the study show that the distribution of referential and display questions is equally used since the majority of the informants $(95.7 \%)$ reveal no difference in distributing their questions. On the other hand, the participants report that referential questions 
generate interaction in the classroom more than any other type of questions. Overall, the first hypothesis stating that there is no difference in the distribution of teachers' display and referential questions in Moroccan EFL classrooms, and the hypothesis revealing that the amount of classroom interaction caused by referential questions is much greater than that caused by display questions are confirmed.

Making an EFL classroom very interactive depends primarily on teachers' ability to ask questions which generate different kinds of learning. It seems that all informants agreed on the importance of asking questions within classrooms as a significant stimulus for generating and exploring different kinds of learning. In this respect, questioning has a great effect on the teaching and learning process and they are part of it. Questions can also be of great aid to check students' comprehension, understanding, and to increase their participation level, and curiosity. The present study's findings are also consistent with Morgan and Saxton's (2006) research findings. In effect, they claim that a good question is an expressive demonstration of genuine curiosity.

Furthermore, it is also found that once questions are well-planned and appropriately administered, they become a good help for teachers as well as for learners. They ensure the easiness of the flow of learning and maximize participation and management. Moreover, questions investigate more and more kinds of learning. Through questions, teachers can get feedback and reflect upon their teaching and asking strategies. They play a crucial role in making the lesson successful through grading materials/ question-asking from simple to complex and they help students develop different learning skills.

According to what has been discussed earlier, the answer to 'What do teachers think of the effect of their questions on EFL classroom interaction as well as on the learning process?' is likely to be positive. For all of this and according to the study's findings, the hypothesis stating that there is a general affirmation that effective teaching depends primarily on teachers' ability to ask questions that generate different kinds of learning, and therefore affect both the learners and the teaching and learning process is confirmed.

\section{CONCLUSION}

This research mainly aimed at investigating and analysing teachers' perceptions of the effect of question-asking on EFL classroom interaction. Several significant findings have been obtained namely, the type of questions that teachers use within classrooms enables, according to what teachers think, students to generate different kinds of learning such as enhancing learners' involvement, creating an interactive environment, and promoting students' critical thinking. Moreover, the distribution of teachers' questions is equally used which reveals the teachers' awareness of the importance of both display and referential questions in the students' learning process. Stressing the fact that referential questions are the type of questions that enables students to be more interactive within classrooms. It helps in making the teaching and learning process successful in the sense that they increase students' participation, critical thinking, and understanding Hence, the use of questioning strategies in learning activities helps teachers primarily evaluate students' knowledge and understanding of their thoughts and enhance interaction in the classroom. However, many issues evolve because nothing guarantees that students learn better. There is also no evidence that students think what the teachers think for the present study represents only teachers' perceptions, and it lacks students' voices and perceptions. In sum, it is necessary for teachers to account for the preeminent importance and the utility of question-asking strategy to improve their practices, classroom management, and 
teaching skills. Further, the new teaching methodologies can be explored to enhance the teaching and learning process.

\section{LIMITATIONS OF THE STUDY}

No research can be carried out without being faced with some obstacles, therefore, this present research study encountered many limitations, which make it difficult but not impossible. First, the findings of this small-scale study cannot be generalisable. However, any findings from any research are generalisable only within that situation and within the context of the work, which is declared in advance. Second, it is worthy-mentioned that using questionnaires to collect data from a large group of people is not always reliable since returns and response rates may be too low to ensure a valid research outcome. Moreover, informants may answer positively to please the research, or in order not to lose face. Third, we have planned to use observation as a method for collecting data, but time constraints make it difficult. Finally, the paucity of references was one of the barriers that hindered us to cover a large area of literature.

\section{PEDAGOGICAL IMPLICATIONS}

It should be pointed out that the results of this study may be particularly very interesting as long as the teaching and learning process is concerned. Question asking is of great importance in EFL classrooms. It is an effective tool for generating different kinds of learning. For example, checking students' understanding and comprehension, enhancing students' critical thinking, helping in creating real-life problem situations, boosting the mastery of different skills, involving learners' in the learning process, and creating a communicative/interactive atmosphere. Therefore, teachers should be aware of the importance of asking questions in developing both the learning process and their teaching practice. Moreover, teachers are advised to plan their questions $b$ to guarantee a promising learning environment and therefore encourage interaction. Another idea is that not only language teachers should be aware of the importance of the different types of questions (display \& referential) and their context of use, but also students should be made aware as well. Along the same line of reasoning, teachers should vary their use of referential and display questions taken into account the learning circumstances and contexts. In brief, teachers are advised to introduce a question as input within classroom discourse that can function as a stimulus towards involving students in interaction. Therefore, engaging teachers in training on the types of questions, questioning strategies, their uses in the English classrooms, ways of preparing questions, and the purposes of questions in the class is compulsory. By so doing, teachers can be equipped with the necessary pedagogical tools to guarantee effective use of questions in the EFL classroom.

\section{SUGGESTIONS FOR FURTHER RESEARCH}

Interpretations of the findings of this present research lead to some meaningful recommendations for further research. Most methodological approaches and views to teaching second / foreign languages show that question-asking is of paramount importance in promoting learners' achievements and developing the learning process. They also show that teachers' questioning behaviour in Moroccan EFL classrooms has a remarkable effect on both the teaching and learning process. Hence, future research should go beyond dealing only with the effect of teachers' questioning behaviour by considering the effect of both textbooks and students' questions on the teaching and learning process. Phrased differently, the researchers 
recommend conducting research discussing the effect of both the activities and exercises of textbooks and students' questions on the development of the teaching and learning process. Besides, the focus should not be only on referential and display questions but also on the other types of questions.

\section{REFERENCES}

Abdul-Ghafour, A. K., \& Alrefaee, Y. (2019). The relationship between language earning strategies and achievement among EFL university students. Applied Linguistics Research Journal, 3(3), 64-83

Becker, M. (2009). Classroom Questioning. Nordest Germany: Deutshen National Bibliothek.

Brock, C. A (1986). The Effects of Referential Questions on ESL Classroom Discourse. TESOL Quarterly, 20, 47-59.

Cecil, L.N. (1995). The Art of Inquiry: Questioning Strategies for K-6 Classrooms (2 ${ }^{\text {nd }}$ ed). Portage \& Main Press.

Cooper, J. M. (1976). Classroom Teaching Skills. United States: Wadsworth. Cengage Learning.

Cullen, R. (1998). Teacher talk and the classroom context. ELT Journal, 52(3), 179-187.

Dalton-Puffer, C. (2007). Discourse in Content, and Language Integrated Learning. Amsterdam. The Netherland: John Benyamin Publishing.

Elenein, A. H. A. A. (2019). The Effect of Utilizing Digital Storytelling on Developing Oral Communication Skills for 5th Grade Students at Rafah Primary Schools. International Journal of Language and Literary Studies, 1(1).

Farahian, M., \& Rezaee, M. (2012). A case study of an EFL teacher's type of questions: An investigation into classroom interaction. Procedia-Social and Behavioral Sciences, 47, 161-167.

Gruyter, W. (1988). Questions and Questioning (M. Meyer, Ed.). Belin: New York. Foundation of communication: library edition.

Ho, D. G. E. (2005). Why do teachers ask the questions they ask? RELC Journal, 36(3), 297-310.

Hornby, A. S. (2000). Oxford Advanced Learner's Dictionary ( $6^{\text {th }}$ ed.). Oxford University Press.

Jeyasala, V. R. (2014). A prelude to practice: Interactive activities for effective communication in English. Alternative pedagogies in the English language \& communication classroom, 164170.

Kao, S. M., Carkin, G., \& Hsu, L. F. (2011). Questioning techniques for promoting language learning with students of limited L2 oral proficiency in a drama-oriented language classroom. Research in Drama Education. The Journal of Applied Theatre and Performance, 16(4), 489-515.

Karnes, A. F., \& Kosak, k. R. S. (2005). Questions for Teaching the Gifted (E. Shaunessy ed.). United States: Prufrock Press, Inc.

Koshy, V. (2005). Action Research for Improving Practice: A practical guide. Great Britain: Cromwell Press, Trowbridge, Wiltshire.

Morgan, N. and Saxton, J. (1991). Teaching, Questioning, and Learning. London: Routledge.

Morgan, N. and Saxton, J. (2006). Asking better questions. Pembroke Publishers. 
Myhill D., Jones S., and Hopper, R. (2006). Book Review: Talking, listening, learning; effective talk in the primary classroom. Open University Press: Maidenhead

Nancy, C (1995). The Art of Inquiry: Questioning Strategies for K-6 Classrooms by Cecil Nancy (199501-01) Paperback.

Nhem, D. (2019). Language Learning Strategies: A Comparative Study of Young and Adolescent Cambodian Learners. International Journal of Language and Literary Studies, 1(2), 34-45. https://doi.org/10.36892/ijlls.v1i2.43

Nunn, R. (1999). The purposes of language teachers' questions. IRAL-International Review of Applied Linguistics in Language Teaching, 37, 23-42.

Rachmawaty, N., \& Ariani, S. (2019). Investigating the Types of Teacher Questions in EFL Secondary Classroom. In Sixth of International Conference on English Language and Teaching (ICOELT 2018). Atlantis Press.

Richards, J. C. (2006). Communicative Language Teaching Today. Cambridge University Press.

Richards, J. C., \& Schmidt, R. W. (2010). Longman dictionary of language teaching and applied linguistics. Routledge.

Toro, V. Minuche, G. C. Tapia, E. P. Paredes, F. (2019).The Use of the Communicative Language Teaching Approach to Improve Students' Oral Skills. Canadian Center of Science and Education, 12, 1.

Van Lier, P. L. (1988). The Classroom and the Language Learner. Londres: Longman.

Walsh, J. A., and Sattes, B. D. (2005). Quality of Questioning. California: Corwin Press.

Wragg, E. C., \& Brown, G. (2001). Questioning in the Secondary School. Routledge Falmer.

\section{AUTHORS'BIOS}

Nourreddine Menyani is a PhD holder from Ibn Tofail Kenitra University -Faculty of Arts and Human Sciences- in the department of English. His research interests include Applied Linguistics, Intercultural Communication Competence, Information Communication Technology, pedagogy and Foreign Language Teaching and Learning.

Marwa Merabti is a high school teacher and a doctoral candidate at Ibn Tofail Kenitra University -Faculty of Arts and Human Sciences- in the department of English. She is a master holder in applied linguistics. She is interested in English language teaching, applied linguistics, critical thinking, and ICTs. 